\title{
BANK'S PROFITABILITY IN INDONESIA: CASE STUDY OF ISLAMIC BANKS PERIOD 2008-2012
}

\author{
Faiza Husnayeni Nahar, Nano Prawoto \\ Faculty of Economics and Business, Universitas Muhammadiyah Yogyakarta, \\ Indonesia \\ Jalan Lingkar Selatan, Bantul, Yogyakarta 55183 Indonesia, Phone +62-274-387656 \\ Correspondence E-mail: Faizahusnayeni@umy.ac.id
}

Received: July 2017; Accepted: October 2017

\begin{abstract}
Islamic banking is industry sector that contributes to influence the country's economic growth. As it is necessary to control the quality of bank performance, being banking regulator, Bank Indonesia has responsibility to assess the financial performance of the banks, among which is to see the level of profitability by using Return on Assets (ROA) ratio. The aim of this study is to empirically test a model that links factors such as inflation, Gross Domestic Product (GDP), Capital Adequacy Ratio (CAR), Financing Deposit Ratio (FDR), Non Performing Financing Ratio (NPF) and Operating Expenses over Operating Income (BOPO) to profitability of Islamic Banks in Indonesia from January 2008 to December 2012. This study use panel data of Islamic banks from monthly financial statement data published by Bank Indonesia. The empirical findings of this paper suggest that inflation, GDP, NPF are found statistically positive significant to bank profitability while CAR, FDR and BOPO have negative sign and statistically significant to bank profitability. Since society prefers to do transaction such as saving and invest money with bank which has good performance. It indirectly contributes to increase the Indonesian economic growth.
\end{abstract}

Keyword: bank's profitability, economic growth, panel data

JEL Classification: F65, O40, C33

\begin{abstract}
Abstrak: Perbankan syariah adalah sektor industri yang berkontribusi mempengaruhi pertumbuhan ekonomi negara. Karena perlu untuk mengendalikan kualitas kinerja bank, sebagai regulator perbankan, Bank Indonesia memiliki tanggung jawab untuk menilai kinerja keuangan bank, antara lain untuk melihat tingkat profitabilitas dengan menggunakan rasio Return on Assets (ROA). Tujuan dari penelitian ini untuk menguji secara empiris model yang menghubungkan faktor-faktor seperti inflasi, Produk Domestik Bruto (PDB), Rasio Kewajiban Penyediaan Modal Minimum atau Capital Adequacy Ratio (CAR), Rasio Deposito Berjangka (FDR), Rasio Operasional Non Performing (NPF) dan Beban Operasional atas Laba Usaha (BOPO) terhadap profitabilitas Bank Syariah di Indonesia mulai Januari 2008 sampai Desember 2012. Studi ini menggunakan data panel bank syariah dari laporan keuangan bulanan yang dipublikasikan oleh Bank Indonesia. Temuan empiris menunjukkan bahwa inflasi, PDB, NPF secara statistik berpengaruh positif signifikan terhadap profitabilitas bank, sementara CAR, FDR dan BOPO memiliki pengaruh yang negatif dan signifikan secara statistik terhadap profitabilitas bank. Karena masyarakat lebih suka melakukan transaksi seperti menabung dan menginvestasikan uangnya dengan bank yang kinerjanya bagus, sehingga secara tidak langsung hal ini turut berkontribusi untuk meningkatkan pertumbuhan ekonomi Indonesia.
\end{abstract}

Kata kunci: bank's profitability, economic growth, panel data

Klasifikasi JEL: F65, O40, C33 


\section{INTRODUCTION}

Bank as a financial institution perform key role in financial activities, like mechanism of payment, perform function like transfer and management risk and dealing with financial market and instrument. As a financial intermediary, banks also play very crucial role and considered very important for economies function (Ashraf, 2012). The bank efficiency would influence the economic growth. Athonasoglou (2005) as cited by Stiawan (2009) stated that insolvencies of bank can lead to crisis as whole. Afterwards the bank profitability contributes in economy and it would endure negative and external financial shocks and affect financial system stability. Therefore, it is important to understand the profitability determination by control bank's quality.

As it is necessary to control the quality of bank performance, being banking regulator, Bank Indonesia has responsibility to assess the financial performance of the banks, among which is to see the level of profitability by using Return on Assets ratio. ROA is ratio that measures bank ability to earn profit as a whole. ROA is important for banks because it is used to measure effectiveness of the company in generating profits by utilizing its assets (Stiawan, 2009). ROA is the ratio of profit after tax to total assets. The greater ROA shows the better performance of the company, because the rate of return is greater.

Nowadays, many researchers who studied determinant of profitability, among the researchers who have studied the effect of factors on bank profitability are Yuliani (2007), Stiawan (2009), Dwijayanthi and Naomi (2009), Pramuka (2010), Prastiyaningtyas (2010), Anto and Wibowo (2012) and Omar Masood (2013). Most of these studies were conducted by using panel data as the analysis tool except two researches by Anto and Wibowo (2012) and Omar Masood (2013) where they used time series with Cointegration and Error Correction Model. In Indonesia, most of the researchers prefer to use panel data than time series in order to get maximal result, hence this research would study about factors that influence bank profitability that use panel data as method.

To investigate the effect of bank's characteristics and macroeconomics determinants toward bank's performance, some variables in the research includes.

\section{Inflation}

Inflation is a rising price in commonly and continuously. Increasing price of one or two goods cannot be called as inflation unless the increasing of price is spread widely to other goods. According to Karim (2007), negative impact of inflation is made people decide economic activity such as consume, invest and produce with hesitation. It debilitates the spirit and society's perspective to save money. Inflation would reduce the society income and standard of living. Besides that, investor are not willing to invest their money in real sector because price which is increase sharply would influence consumption activity and bank cannot distribute the fund and bear the cost, eventually inflation decreases the economic growth of a country. Thus, hypothesis is set as follows:

Hypothesis 1: The higher the level of inflation, the lower will be the level of ROA.

\section{Gross Domestic Product}

GDP is all of goods and services produce by society in a country in certain period, include goods made by foreign people who work in that country (Anto and Wibowo, 2012). There is relation between GDP and banking in term of saving. The most bank activity is to collect society fund and distribute that fund (invest) subsequently profit from investment will be part of Islamic bank profitability (Stiawan, 2009). From 
these arguments, the following hypothesis would be derived as follows:

Hypothesis 2: The higher the level of GDP, the lower will be the level of ROA.

\section{Capital Adequacy Ratio}

CAR is ratio that used to measure the ability of capital to cover potential losses in lending activity. By standardized the amount of CAR, the higher capital adequacy which owned by bank would deflate the potential risk as the impact of expansion asset especially asset which involve profit or risk (Dewi, 2010). Afterwards, the high ratio of CAR would decrease the bank problem then bank could increase the performance well. Therefore, the hypothesis is:

Hypothesis 3: The higher the Capital Adequacy Ratio, the higher will be the level of profitability

\section{Financing Deposit Ratio}

FDR is a ratio that indicates the bank performance in term of financing. If the amount of FDR is high, the bank liquidity would be low since bank distributes the larger fund to costumer. Afterwards the customer would return back the fund plus additional, that additional would be part of bank profitability. Thus, hypothesis that:

Hypothesis 4: The higher the level of FDR, the higher will be the level of ROA

\section{Non-Performing Financing}

NPF is a ratio that measures financing risk. Financing risk is the risk due to the inability of the customer to return the loan accordance with a predetermined time period. The higher amount of NPF would affect the bank activity like funding the other productive asset since the costumer cannot return the loan. High NPF indicate the bank performance is bad in term of financing. Then the hypothesis is:

Hypothesis 5: the lower the level of NPF, the higher will be the level of ROA

\section{Operating Expenses over Operating Income}

$\mathrm{BOPO}$ is ratio that used to measure the efficiency of bank operational. Since efficiency of bank is important, we have to achieve the lowest level of BOPO then profit would be earned. However, if BOPO located in high level, it indicated that bank have not capable to manage the operational expenses, hence the profit would be decline. The hypothesis namely:

Hypothesis 6: the lower the Operating Expenses over Operating Income ratio (BOPO), the higher will be the level of profitability (ROA).

\section{RESEARCH METHOD}

This paper aims to answer to the question of what are the factors that may cause bank profitability. To answer the question, an empirical study is pursued by using panel data including ROA, inflation, GDP, FDR, NPF and BOPO on Islamic Commercial Bank in Indonesia. The data used in this paper was collected from Islamic Commercial Banks that listed and published by Bank Indonesia (banking regulator) from January 2008 to December 2012. In this case, the Islamic Commercial Banks are Muamalat Indonesia Bank, Sharia Mandiri Bank and Mega Sharia Indonesia Bank since only these banks which required financial monthly report and it is General Islamic Bank.

There are several benefits by using panel data, which are (1) reducing omitted variable problem, (2) increase degree of freedom, (3) reducing collinearity among explanatory variables, (4) provide a better solution in dynamic change inference rather than cross section, (5) capable to account the heterogeneity individual explicitly by allowing individual specific variables and (6) used to minimize the bias that may be caused by the aggregation of individual data (Muryanto, 2009). 
By these advantages, panel data is not necessary to do classical assumption test (Gujarati, 2003). The general form of panel data can be written as follows:

$Y_{i t}=\alpha+\beta X_{i t}+\mu_{i t}$

Assumed that $i=1,2,3,4$...etc and $t=1,2, \ldots$ etc so the regression can be written as follows:

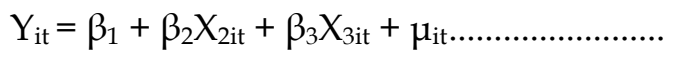

Explanation:

$\mathrm{i} \quad=1,2, \ldots, \mathrm{N}$ (cross section dimention)

$\mathrm{t} \quad=1,2, \ldots, \mathrm{T}$ (time series dimention)

$\mathrm{Y}_{\mathrm{it}} \quad=$ Dependent variable in the time of $\mathrm{t}$ and unit i

$X_{i t}=$ Set from independent variable in the time of $t$ and unit $i$

$\mathrm{a}=$ Constanta

$\beta=$ Constanta from independent variable in the time of $t$ and unit $i$ and uit

$\mu_{\text {it }} \quad=$ error

Hence, the model used in this research was obtained from the equation (1) and (2) namely:

$Y_{i t}=\beta_{0}+\beta_{1} X_{1 i t}+\beta_{2} X_{2 i t}+\beta_{3} X_{3 i t}+\beta_{4} X_{4 i t}+\beta_{5} X_{5 i t}+$

$\beta_{6} X_{6 i t}+\beta_{7} X_{7 i t}+\mu_{i t}$

Explanation:

$\mathrm{Y} \quad=$ Return On Asset

$\mathrm{X}_{1} \quad=$ Inflation

$\mathrm{X}_{2}=$ Gross Domestic Product (GDP)

$\mathrm{X}_{3}=$ Capital Adequacy Ratio (CAR)

$\mathrm{X}_{4} \quad=$ Financing Deposit Ratio (FDR)

$X_{5}=$ Non Performing Financing (NPF)

$\mathrm{X}_{6}=$ Operational Expenses over Operational Income (BOPO)

$\beta \quad=$ Constanta from independent variable in the time of $t$ and unit $i$ and uit

uit $\quad=$ error

\section{RESULT AND DISCUSSION}

In this research, data panel is the model to test whether independent variables influence the dependent variable. There are two approaches to estimate the regression model namely Fixed Effect Model and Random Effect Model. To select the best model, it is needed to do the specification test namely $\mathrm{F}$ test. $\mathrm{F}$ test formula is:

$F$ table $=F$ statistic

$$
\begin{aligned}
& (\alpha ; d f(N-1, N T-N-K) \\
& =\frac{\left(R^{2} R E-R^{2} F E\right) /(N-1)}{\left(1-R^{2} R E\right) /(N T-N-K)}
\end{aligned}
$$

Whereas $R^{2} R E=\mathrm{R}$ square from Random Effect Model, $R^{2} F E=\mathrm{R}$ squares from Fixed Effect Model, $\mathrm{N}=$ Number of Corporation (cross section), NT $=$ amount of companies $\mathrm{x}$ amount of data, $\mathrm{K}=$ amount of independent variables. The discussion is:

$$
\begin{aligned}
&(\alpha ; d f(N-1, N T-N-K) \\
& \quad=\frac{\left(R^{2} R E-R^{2} F E\right) /(N-1)}{\left(1-R^{2} R E\right) /(N T-N-K)}
\end{aligned}
$$

$$
\begin{array}{r}
(5 \% ; d f(3-1,3.5-3-6) \\
=\frac{(0.831209-0.875468) /(3-1)}{(1-0.831209) /(3.5-3-6)} \\
\left(5 \% ; d f(3,6)=\frac{(0.831209-0.875468)) /(2)}{0.168791 /(6)}\right. \\
5 \% ;(8.94)=\frac{-0.0221295}{0.028131} \\
5 \% ;(8.94)=-0.786658
\end{array}
$$

F statistic is -0.786658 and $\mathrm{F}$ table from numerator of 3 and denumerator of 6 at $5 \%$ alpha is 8.94 . It can be concluded that the hypothesis $\mathrm{H}_{0}$ is accepted $\left(\mathrm{H}_{0}=\right.$ Fixed Effect Model and $\mathrm{H}_{1}=$ Random effect Model) because F statistic less than 
F table $(-0.786658<8.94)$ so the model used in this research is the Fixed Effects Model.

Table 1

Result of Fixed Effect Model

\begin{tabular}{lll}
\hline & Dependent variable: ROA \\
\hline Variable & Coefficient & Probability \\
\hline INF? & 0.006469 & $0.0229^{* *}$ \\
\hline GDP & 2.392895 & $0.0000^{* *}$ \\
\hline CAR? & -0.165760 & $0.0000^{* *}$ \\
\hline FDR? & -0.024568 & $0.0021^{* *}$ \\
\hline NPF? & 0.246247 & $0.0000^{* *}$ \\
\hline BOPO? & -0.122804 & $0.0000^{* *}$ \\
\hline BMI-C & \multicolumn{1}{c}{ Fixed Effect } & \\
\hline BSM-C & -0.067690 & \\
\hline MEGA-C & -0.251086 & \\
\hline & 0.318776 & \\
\hline R & & \\
\hline Adj. R & & \\
\hline F statistic & 0.875468 & \\
\hline Prob. F Stat & 0.869642 & \\
\hline Durbin Watson & 150.2683 & \\
\hline Explanation & 0.000000 & \\
\hline
\end{tabular}

Explanation: *: Significant in level of 10\%, **: Significant in level of 5\%

Source: Data Analysis Result

Based on the general equation, the regression results are:

$\begin{array}{ll}\mathrm{ROA} B M I & =-0.067690+0.006469 \mathrm{INF}+2.392895 \mathrm{GDP}-0.165760 \mathrm{CAR}-0.024568 \mathrm{FDR}+0.246247 \\ & \text { NPF }-0.122804 \mathrm{BOPO}+\mu_{\mathrm{it}} \ldots \ldots \ldots \ldots \ldots \ldots \ldots \ldots \ldots \ldots \ldots \ldots\end{array}$

ROA BSM $=-0.251086+0.006469 \mathrm{INF}+2.392895$ GDP -0.165760 CAR -0.024568 FDR +0.246247

$\mathrm{NPF}-0.122804 \mathrm{BOPO}+\mu_{\mathrm{it}}$

ROA MEGA $=0.318776+0.006469 \mathrm{INF}+2.392895 \mathrm{GDP}-0.165760 \mathrm{CAR}-0.024568 \mathrm{FDR}+0.246247 \mathrm{NPF}$

$$
-0.122804 \mathrm{BOPO}+\mu_{\mathrm{it}}
$$

\section{a) Inflation (INF)}

The coefficient of inflation is 0.006469, means that if inflation rise by $1 \%$ then ROA will increase by $0.06 \%$, assuming there is no changing in the amount of independent variable. Coefficient of inflation is positive so inflation has positive relation to profitability of Islamic bank. It does not match with the variable hypothesis "Inflation has negative effect to ROA". According to Dwijayanthy and Naomi (2009), inflation influences the bank performance, especially reducing profitability of bank. Besides that, inflation gives the negative impact to banking. Bank has potential risk because of rising inflation. Many people hesitate to doing economic activity such as consumption, investment and production. The relationship between bank and society is bank will do not get society fund in maximum amount then bank cannot distribute the fund to people who run the business well. 
However, if the result of research contradicts with the variable hypothesis, there is reason behind that. By looking the amount of inflation in the period of 2008-2012, actually inflation located in the safe point which means that inflation do not rise in hyper amount (hyperinflation) because inflation only rise for 0.24 in 2010, then inflation increase for $0.25 \%$ in 2011. By rising inflation, all of goods will be expensive in the market. Corporations have difficulties to cover the operational cost which over from their corporation revenue so corporations need bank to cover it. It can be concluded that bank as financial intermediary has important position to help the corporation, company, business which all of them is real sector.

\section{b) Gross Domestic Product (GDP)}

The coefficient of GDP is 2.392895, means that if GDP rise by $1 \%$ then ROA will increase by $2.39 \%$, assuming that there is no changing in the amount of independent variable. Coefficient of GDP is positive so GDP has positive relation to profitability of Islamic bank. It matches with the variable hypothesis "GDP has positive effect to ROA". According to Stiawan (2009) GDP has positive correlation with the society income. If society gets income more than usual then they will save their money to the bank. Bank can collect the fund maximally from them and can distribute it well into two ways, first bank distribute fund in the form of investment and second bank distribute fund to society who want to run the business. Finally, bank will get the profit from those ways.

\section{c) Capital Adequacy Ratio (CAR)}

The coefficient of CAR is - 0.165760, means that if CAR rise for $1 \%$ then $\mathrm{ROA}$ will decrease for $0.17 \%$, assuming there is no changing in the amount of independent variable. Coefficient of CAR is negative so CAR has negative relation to profitability of Islamic bank. It does not match with the variable hypothesis "CAR has positive effect to ROA". Supposedly, according to Hesti, CAR is the control variable which influences the profitability of Islamic bank. If bank has capital adequacy it will minimize the bank problem. Therefore, the rising of CAR will increase the profit (Prastiyaningtyas, 2010).

However, the result of study stated that rising of CAR will reduce the amount of ROA. It happens because CAR does not influence ROA maximally.

Although financing provide dominant contribution to generate profit, customer have not been able to return the fund and it will impact to the capital bank. Despite bank has capital adequacy which is $8 \%$ from asset, it cannot cover that losses.

\section{d) Financing Deposit Ratio (FDR)}

The coefficient of FDR is - 0.024568 , means that if FDR rise by $1 \%$ then ROA will decrease by $0.025 \%$, assuming there is no changing in the amount of independent variable. Coefficient of FDR is negative so FDR has negative relation to profitability of Islamic bank. It does not match with the variable hypothesis "FDR has positive effect to ROA".

According to Mulyono, the result of research does not match with the theory of Edward W. Reed who revealed that bank financing provides dominant contribution to get profit almost $90 \%$. It can conclude that FDR has positive influence to profitability of Islamic bank (Nurkhosidah, 2009).

In the other hand, according to Rusyami, the higher amount of FDR will reduce the profitability of Islamic bank. Bank will get the optimal profit if bank invest their liquidity into productive asset in the long term period in the purpose to get additional fund for daily cost. However, this action is risky if people cannot return the debt then bank do not get the 
additional fund that they expect. Therefore, bank will unable to re-invest then the profit will be decrease (Nurkosidah, 2009).

\section{e) Non Performing Finance (NPF)}

The coefficient of NPF is 0.246247 , means that if NPF rise by $1 \%$ then ROA will increase by $0.25 \%$, assuming that there is no changing in the amount of independent variable. Coefficient of NPF is positive so NPF has positive relation to profitability of Islamic bank. It is not match with the variable hypothesis "NPF has negative effect to ROA". This result research is not match with the research from Stiawan (2009), Dewi (2010), Nurkhosidah (2009) and Pramuka (2010) which stated that the higher the NPF ratio, the lower the profitability. It is because the higher the ratio indicates the bad performance a bank, which also means that bank cannot handle the risk of financing problem in which many borrowers cannot return the fund so that bank get losses.

In this research, there is positive relationship between NPF and ROA as the increment of NPF ratio is in a precise standard. The ratio of NPF is $0.24 \%$ and the best standard is less than 5\% (Nurkhosidah, 2009). Hence, despite NPF is raised, the income received by the Islamic banks will not decline. Moreover, Islamic banks are always disbursed the financing by the precautionary principle to finance the parties who need it.

\section{f) Operational Cost per Operational Cost (BOPO)}

The coefficient of BOPO is 0.122804 , means that if $\mathrm{BOPO}$ rise by $1 \%$ then profitability of Islamic bank (ROA) will increase by $0.123 \%$ by assuming that there is no changing in the amount of independent variable. Coefficient of BOPO is negative so $\mathrm{BOPO}$ has negative relation to profitability of Islamic bank. It matches with the variable hypothesis "BOPO has negative effect to ROA". This research matches with the Stiawan's research (2009) which stated that the lower the $\mathrm{BOPO}$ ratio, the higher the profitability. It is because the lower the ratio indicates the good performance a bank, which is also mean that bank can handle the operational cost efficiently and increases the profitability of Islamic bank. Almilia and Herdaningtyas (2005) as cited by Stiawan (2009) stated that efficiency is one of important things to determine the profit of bank. Bank will get profit if bank can spend the operational cost less than bank revenue and bank will get losses if bank spend the operational cost more than bank revenue.

\section{CONCLUSION}

Based on the regression results, the conclusion of inflation, Gross Domestic Product (GDP), Capital Adequacy Ratio (CAR), Financing Deposit Ratio (FDR), Non Performing Finance (NPF) and Operational Cost per Operational Income (BOPO) influence Return on Assets (ROA) are:

1. Inflation (H1) influences positively and significantly to Return on Asset (ROA). This result does not match with the hypothesis "Inflation influence ROA negatively significantly" because the increment of inflation only around $0.01 \%$ which does not too influence ROA even do not close to hyperinflation. It indicates that the higher the inflation, the higher the ROA.

2. Gross Domestic Product (GDP) $\left(\mathrm{H}_{2}\right)$ influence positively and significantly to Return on Asset (ROA). This result matches with the hypothesis then it indicates that the higher the GDP, the higher the ROA.

3. Capital Adequacy Ratio (CAR) $\left(\mathrm{H}_{3}\right)$ influences negatively and significantly to Return on Asset (ROA). This result does not match with the hypothesis "CAR influence positive significant to ROA" because CAR do not influence ROA maximally. The dominant 
contribution to generate profit is financing, so if bank has problem with this financing, it will impact to capital adequacy which cannot cover losses. It indicates that the higher the CAR, the lower the ROA.

4. Financing Deposit Ratio (FDR) $\left(\mathrm{H}_{4}\right)$ influence negatively and significant to Return on Asset (ROA). This result does not match with the hypothesis "FDR influence positive significant to ROA" because financing is risky if the borrower cannot return the fund as financing is the dominant contribution then it will impact to the profitability. It indicates that the higher the FDR, the lower the ROA.

5. Non Performing Finance (NPF) $\left(\mathrm{H}_{5}\right)$ influences positively and significantly to Return on Asset (ROA). This is does not match with the hypothesis "NPF influence negative and significant to ROA" because the increment of NPF is in a precise standard. Hence, despite NPF is raised, the income received by Islamic bank do not decline. It indicates that the higher the NPF, the higher the ROA.

6. Operational Cost per Operational Income $(\mathrm{BOPO})$ or $\left(\mathrm{H}_{5}\right)$ influence negatively and significant to Return on Asset (ROA). This is match with the hypothesis and indicate that the higher the BOPO, the lower the ROA.

7. The amount of Adjusted $R$ squared is 0.879602 , it shows that statistically, inflation, Gross Domestic Product (GDP), Capital Adequacy Ratio (CAR), Financing Deposit Ratio (FDR), Non Performing Finance (NPF) and Operational Cost per Operational Income (BOPO) influence ROA in $87.5 \%$ while the other variable (out of this model) influence ROA for $12.5 \%$.

\section{REFFERENCES}

Anto and Wibowo, G., (2012). Faktor-Faktor Penentu Tingkat Profitabilitas Bank Umum Syariah di Indonesia. Jurnal Ekonomi Islam La_Riba Vol. 6, No. 2, UIN Sunan Kalijaga, Yogyakarta.

Dewi, Dhika R., (2010), "Faktor-Faktor yang Mempengaruhi Profitabilitas Bank Syariah di Indonesia. Universitas Indonesia, Jakarta.

Dwijayanthy, F. and Naomi. (2009). Analisis Pengaruh Inflasi, BI Rate, dan Nilai Tukar Mata Uang terhadap Profitabilitas Bank Periode 2003-2007. Journal Karisma Vol. 3, No. 2: 87-98, Universitas Paramadina, Jakarta.

Gujarati, Damodar, (2003). Basic Econometric fourth edition. New York: The McGraw-Hill Companies, Inc.

Irawan. (2013). Faktor-Faktor yang Mempengaruhi Produk Domestic Regional Bruto Pasca Otonomi Daerah (Studi Kasus di Kabupaten/Kota Daerah Istimewa Yogyakarta). Universitas Muhammadiyah Yogyakarta, Yogyakarta.

Karim, A. (2007). Ekonomi Makro Islam. PT. Raja Grafindo Persada, Depok, Indonesia

Nurkhosidah, S. (2009). Analisis Pengaruh Variabel Non Performing Financing, Penyisihan Penghapusan Aktiva Produktif, Financing to Deposit Ratio, Biaya Operasional per Pendapatan Operasional terhadap Profitabilitas pada Bank Syariah Mandiri. UIN Sunan Kalijaga, Yogyakarta.

Masood, O. (2013). Does Co-Integration and Causal Relationship Exist between the NonStationary Variable for Chinese Bank's Profitability? Empirical Evidence. The EuroMediterranean Economics and Finance Review. Paris, French.

Masood, O. and Ashraf. (2012). Bank-specific and Macroeconomic profitability determinants of 
Islamic banks (The Case of Different Countries). Emerald Insight.

Muryanto, Budi, (2009). Optimalisasi Investasi pada Pasar Modal dengan Peralatan Analisis Hubungan Harga Saham dan Rasio Keuangan. Universitas Indonesia, Jakarta.

Pramuka, Bambang Agus, (2010). Faktor-Faktor yang Berpengaruh terhadap Tingkat Profitabilitas Bank Umum Syariah. Journal of Accounting, Business Management and Public Sector Vol. 7, No.1, Universitas Jenderal Soedirman Purwokerto.

Prastiyaningtyas, F. (2010). Faktor-Faktor yang Mempengaruhi Profitabilitas Perbankan (Studi pada Bank Umum Go Public yang Listed di Bursa Efek Indonesia tahun 20052008. Universitas Diponegoro, Semarang.

Stiawan, A. (2009). Analisis Pengaruh Faktor Makroekonomi, Pangsa Pasar dan Karakteristik Bank terhadap Profitabilitas Bank Syariah: Studi pada Bank Syariah periode 2005-2008. Universitas Diponegoro, Semarang.

Yuliani, (2007). Hubungan Efisiensi Operasional dengan Kinerja Profitabilitas pada Sektor Perbankan yang Go Publik di Bursa Efek Jakarta. Journal of Management and Business Sriwijaya Vol. 5, No. 10, Universitas Sriwijaya, Palembang.

Bank Indonesia, 2008-2011, Monthly Finance Report.

Bank Indonesia, 2008-2009, Quarterly Finance Report.

, 2007, Publication Letter Number

9/24/DpbS.

2008, Bank Indonesia Regulation

Number: 10/15/2008.

2013, Syariah Banking Statistic.

The Law of Indonesia Number 21 of 2008 about Syariah Banking.

The Law Number 10 of 1998 about The Change of the Law Number 7 of 1992 about Banking.

www.bi.go.id www.muamalatbank.com

www.syariahmandiri.co.id

www.bsmi.co.id 